\title{
'Average intellectuals' and the Middle ages : an introduction with translation, and apparatus.
}

Camille Akmut 
Description : A collection of previously released articles, that belonged and were done together.

\section{Introduction : an intellectual triptych}

In the following, the reader will find, in the tradition of Medieval scholasticism, though in great transgression of it also needless to say, an "intellectual triptych" formed by :

1. An introduction, that is also a commentary of a work of a master.

2. A translation with marginal notes of the same.

3. A commentary of the translation.

Commentaries and translations, and their commentaries and translations, constituted the "bulk" of intellectual activity in the Middle ages. That of average intellectuals - we use this term here no other meaning, and no smirk.

But, "middle", or "average" as we write conforming to the original French, we know many of our contemporary intellectuals, academics to be : it is a commentary of them, most. An intellectual triptych on Intellectuals in the Middle Ages.

Yet, also an "annunciation" of these other intellectuals, that had not yet quite come to recognize themselves to be so (in the 12th c.).

The triptychs of Van Eyck, Durer or Bosch (The Garden of Earthly Delights in particular) : motifs of the same, different, but the same. Or, "Variations on a theme" to use the language of composers.

But, most :

And, these others yet, that we now know to be : computer scientists.

They are not unlike these scholars, who did know who they were, and certainly had no idea where they were going. - just like their forefathers.

Perhaps, they too, will one day join us in the 'world of the city', and feel the same attraction to 'urban schools'.

They will be included in a yet unfinished wooden panel. 


\title{
Intellectuals in the Middle Ages, Jacques Le Goff. - Birth of a social category, and discipline.
}

\author{
Camille Akmut
}

\begin{abstract}
Intellectuals in the Middle Ages: birth of a social category, and also simultaneously discipline. A radical book - important to history like few are: with this small monograph, Jacques Le Goff created "historical sociology" or "sociological history"; and liberated countless others.
\end{abstract}




\section{A foundational "mistake"}

A "foundational" - and intended - anachronism creates an entire subfield. Mistake : literally, when something is taken for other than it is. But, this foundational "mistake" made it so that : it became what it should have always been perhaps.

Now, variously called "historical sociology" or "sociological history", we have not quite agreed yet, on our own terms, tools.

In this radical book - important to history like few are, Jacques Le Goff reinvented his discipline, or a new one. - we are not sure.

In doing so, he is the peer of Michel Foucault and Erwin Panofsky that is his place.

In great intellectuals, even the mistakes are beautiful, as some say about Panofsky, for instance, whose analysis of the "Arnolfini Portrait", currently debated, is and in truth always was more important than the portrait itself. - even if they did end up reaching a consensus that disproved his flamboyant thesis of a painted contract, theirs would never have the same allure. He made us dream, at least.

But, let us perhaps here try to create or recreate his or its genealogy.

Published in $1957^{1}$, what models or peers did it, and he have? What models could Le Goff, who was 30 years old at the time of the publication of this great book, have looked up too?

One - one possible one - is Gothic Architecture and Scholasticism published in 1951. (While the 1953 Early Netherlandish Painting is often overlooked.) Was Le Goff aware of Panofsky then? We just don't know, but think it unlikely. (They did share the same era.)

Closer to him would have been the historians of the Annales, this legendary journal of legendary historians: French, as he was, many of them specialists of the Middle Ages too : Marc Bloch and Lucien Febvre to name a few.

Les Rois thaumaturges (1924), The Problem of Disbelief... (1942) ...

(Marc Bloch, who, like Cavailles, could have escaped his duty, had joined the Resistance instead, with the ends we know : imprisonement preceded execution by firing squad. A boy next to him, he comforted in their last moments : "my boy, everything will be fine"... And, they fired. And, so, died one of the truly great historians of the past century.)

Madness and Civilization was published in 1961 for the first time.

Greek Homosexuality, another work that we assign here to this great tradition of sociological history, in turn was published much later, 1978.

A meteorite fallen from the sky : "lonely, but not alone".

They are our peers, and fathers : us, who conceived of history as more than mere accumulation of dates; celebration of kings, queens, ladies and dames; hagiography of the lives of saints, old and new; comfortable, sometimes dangerous recollections, if not inventions of our "origins".

\footnotetext{
${ }^{1}$ Le Goff, Jacques. 1957. Les Intellectuels au Moyen Age. Seuil.
} 
But, speaking of "saints" and "holy" figures, we also never forget the lines in the Communist Manifesto about slaves and masters, patricians and plebeians... Marx : father to all - fathers, sons, and daughters, deserving of their parents (or not).

In Durkheim, we also find in many places the earliest antecedents of this specific type of history : so, for instance, in mesmerizing passages where he makes broad - we would say "structural" now - analyses of the differences between the educations of the page and villein (the former learned the arts of chivalry, the latter arithmetic, songs and grammar), which he compares to that existing between that of the Brahman and Sudra - "world history", anachronistically still.

We said "(foundational) anachronism", why? Well : the term, the modern term and model of "intellectual" did not exist in the Middle Ages as such, it existed but with some other conflicting meaning (they who make intelligible with intuition);

We also say "model" because these scholars had other visions and conceptions of intellectual activity as well : while we place much value on originality, they put much energy instead into copying, and commentaries, and did not conceive of neither as an inferior activity. We add here, that, in doing so, they were like pre-modern painters : a good copy was no less, and more perhaps?

How will the intellectuals of the 24th c. be? What will they look like? Where will they place their value? And, finally : will we return to dark ages of looking at stars and celestial objects with dumb amazement, or will be among them?

Just as talking of "homosexuality" in Greek antiquity poses a problem, as this terminology was unknown then (an invention of the 19th c.); the specific model of "pederasty" in Ancient Athens instead existed.

A problem that did not deter Kenneth Dover, whose work's influence on Foucault we know, from calling his book: Greek Homosexuality. Another foundational, intended anachronism. Happy mistake, or happy ending? (Intercrural sex, or "between-the-thighs".)

He even left out the "Ancient" part. Any more a transgression, and he would have needed to drop the capitalization in both terms.

This other great academic, who, otherwise incarnated the commonplace figure of the intellectual, in clothing and titles, spoke of adolescent boys as the "pin-up's" of the days. Transgressions that create insights.

Whoever is able to write the next book on "A History of Humanity on Mars" (conceived as our relationship throughout time to that planet) or "Queer in the Middle Ages" is guaranteed to have a place, if not in history, in our hearts.

(The state of the historiography of "homosexuality" in the Middle Ages is nothing short of amazing and catastrophic, with the books of one historian dominating all debates, for lack of alternatives, who reminds us of our modern ones who try to establish the "positive aspects" of various periods, from Colonialism to the Nazis... Meanwhile, he spends his time and energies on highlighting the "tolerance" of the Christian Church. But, at what point, between lighting the match and poring gasoline on someone, where these Churchmen of the Middle Ages "tolerant"? Imbecile.) 
Intellectuals in the Middle Ages: birth of a social category and also simultaneously discipline.

\section{Liberation of one, and many}

Jacques Le Goff, in what is ostensibly a book for few readers, but only superficially so, gave us new liberties, as intellectuals, we did not know ourselves to know, or have - he liberated himself, and countless others;

All the while reminding us of our own history.

"It is hard to not feel some form of adoration for intellectuals like that", we wrote about another social (or sociological) historian, Christophe Charle, with whom Le Goff had co-written. It is.

No footnotes, entire pages devoid of any dates; so much left out, we are only left with the gold that comes out of mud; and, only, that that can be separated by an expert. While reading this book, we know ourselves to be in good company, and never alone.

We read it with the feeling of being constantly guided by a great, gentle, somewhat scary giant. Like Virgil to Dante in the Divine Comedy.

(In real life, he was a stern, if not grave figure, who spoke with a steady, voice - there was something a bit monstrous about it, as Canguilhem had written about Cavailles. And, for some reason, he reminds us of gargantuan figures like Welles or Melville.)

Intellectuals in the Middle Ages was the PhD thesis of Jacques Le Goff.

Did it really look like this when it was defended? We miss a history of this great book. How did it even get published? (We do not even know who its supervisor was. But, perhaps this plays no role, as, rarely, we encounter such beautiful books, that are so obviously product of one person, a singular vision.)

In this, in truth, strange, strange book - queer like we like - Jacques Le Goff speaks interchangeably of "workers" and their "tools", and imaginarium and habits, to describe intellectuals at work.

Saint Jerome, in his study, would have fallen from his chair. Or, perhaps this is the fate of all the Saint Jerome's and Saint Anna's of our times. We cannot mistake these anachronistic scholars for intellectuals : they are in the 21 st century, as they were in the 12 th. They are "tools", in the other meaning we know this word to have, because they don't control theirs. Slaves of themselves, masters of many others.

In concluding this review, allow us one last of the few pleasures that we are allowed as intellectuals : average intellectuals and academics (moyen) will certainly find much to learn in this book on the Middle Ages...

Les Intellectuels au Moyen Age.

The intellectuals of the 21 st century are computer scientists : it is to them that we turn now.

Tools unknown live lives of their own... 


\section{References}

Le Goff, Jacques. 1993. Intellectuals in the Middle Ages. Wiley-Blackwell.

—. 20191. "The History of Computer Science and Technology. Reflection of a reflection : a (peer) review."

—. 2019s. "Beauty in the 'World Outside' is Most Pure Imperfect: The Anti-Iconography of the Friedsam Annunciation".

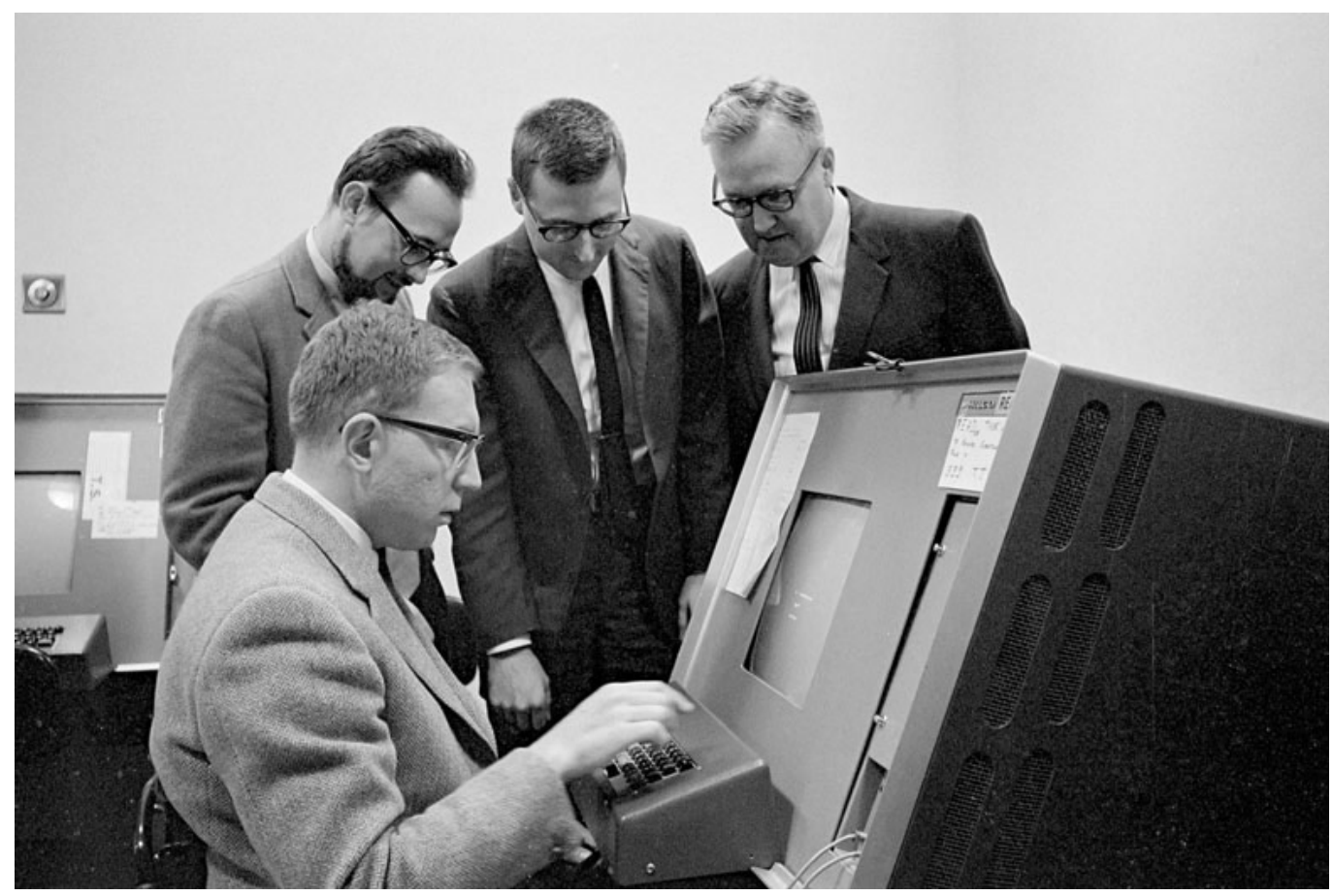

Figure 1: Intellectuals at work. Edward "Ed" Feigenbaum (Turing Award 1994).

(Image credit: Chuck Painter) 


\section{Average intellectuals I \\ Intellectuels Moyens new translation of Jacques Le Goff's \\ Intellectuals in the Middle Ages}

Camille Akmut

(with introduction and critical apparatus) 
To my colleagues at the University of Vienna, one of the Medieval universities described in Intellectuals in the Middle Ages, and intellectual centers of the world in the 1930s of the "The School of Vienna at Prague". The role of history : to put ourselves in distant pasts, to remind us of our times, "reflection of a reflection".

As to "average" (moyen), everyday academics living in the 21st century as these scholars did in the 12th, they will perhaps, one day, too, undergo the same transitions described in the following pages. 


\section{The transition from monastic life to 'world of the city'}

\section{PREFACE}

It might seem a little presumptuous to publish again today a history book, exactly as it was seventy years ago - with no modifications. But, I do not believe that its descriptions of the scholarly and academic world of the Middle Ages are 'past its use-by date'. It seems to me, on the contrary, that there are great resemblances, and that its central point of view remains ours.

Beginning with the word "intellectual", whose interest to us lies in the fact that it shifts our attention from institutions, and their buildings, to people, flesh and blood, from ideas to social structures - practices and mental structures, of placing this phenomenon of universities in the Middle Ages inside a bigger history, that of the "longue duree", and sociology.

The fashion of "intellectual history", a fashion fad.

If, like in any good comparative approach, we do not separate sociology from history, the anachronism of "intellectual" is justified and useful. The point of view of the sociologist enhances that of the historian : the sociologist establishes coherence of "models", "categories" and general "types", while historians highlight change, turns and breaches, and differences, and ruptures.

This notion of "intellectual", I borrowed from modern history, the sociology and epistemology of our world since the 19th c.. I certainly did not intend to give myself over to a theoretical analysis of this concept.

It is no coincidence that all the best studies on intellectuals have come out of the Italy of Gramsci [and Marx]. (...)

I am relieved, to come back to "my intellectuals", of having seen a wonderful study on the birth of the University of Modena, the second Italian university after Bologna.

Giovanni Santini, referring to my book of 1957, has posited much better than I ever did :

The birth of the "intellectual", as a social category, a new sociological type, presupposes the division of labor seen in urban spaces, just like university [scholarly] institutions presuppose a common cultural, scientific ground; in which these new "cathedrals of knowledge" are able to emerge, and flourish, and confront themselves.

The division of labor... The city... New institutions...
- These intellectual "intellectual histor[ians]" - doubly imprisoned - are like the fashion victims of our days.

- Like telescopes are to microscopes, and sniper rifles to bombs.

- And, certainly no "diatribes", like a certain dumb, dumb historian of science from Yale, who said he could go into "long diatribes", and managed the extraordinary feat of a 3-hour long, real or imagined, presentation on errors in calculations among the scribes of Mesopotamia. - out of which came nothing, other than he was the error himself.

- "People in the city have peculiar tastes", said Reed, who knew what he was talking, and had lived many lives contrary to certain others.

- Giovanni's Room. (In the "tolerant" Middle Ages of Christianity, they pored gasoline on people like James Baldwin and Michel Foucault, and lit the match too.) 
A common cultural ground : that was common to all of Christianity, in opposition to the fragmentation, political and geographical, characteristic of the High Middle Ages.

These were, in short, the needed and essential steps and characteristics that made, and had made possible, the transition towards and emergence of the new intellectual landscape of the turn of the 12 th and 13 th $\mathrm{c}$. .

Indeed, the link of the intellectual to the city played a decisive role. - in the Middle Ages.

The evolution of scholarly and academic practices can only be understood in that context : the urban revolutions, of the 10th to 13 th c..

The divide [cleavage] between the monastic school, reserved to monks (in training), and the urban school, in theory open to all, including to those who would remain agnostic [laic], is fundamental.

But, I should have done more to highlight the attraction of urban schools and spaces on the monastic world of these scholastic monks.

If, ' 5 by 5', the orders of the Beggars - despite the debate launched by Saint Francis of the Fransiscans - had right away joined the 'world of the city' and its schools, this was not so for all :

Even more significant is the conversion of certain average intellectuals found in the 'monastic world', e.g. Cistercians, to academic teaching.

They did so by founding colleges for [the sins of] their orders in the academic cities of the 13 th c. onwards.

Urban, these new intellectuals :

These new Men of some profession, or trade, have - just like merchants, as they are in facts "merchants of words", as others are "sellers (ideologues) of times" - to fight the cliches of a science that is not for sale, being a gift of God.

Following the American historian of the Middle Ages, Gaines Post I have highlighted the professional character and nature of these new masters and scholar-students.

In addition to the great books of Pearl Kibre, a series of studies have shown precisely the 'material conditions of possibility' - material, technical, if not technological, law, and else - of the academic profession.

In that way, I should have insisted more on the revolutionary role played by academic curricula in recruiting governing [government] elites.

The Western World had only known three modes of access to power up to that point :

\section{Birth, the most important.}

2. Riches, very secondary until the 13th c.. With the excep-
- Pure Marx, Durkheim, Panofsky.

- If you do not understand the relevance of passages such as these to our present times, we cannot help you, you must help yourself.

- In fact, the original says "milieu monastique". And, we have come to know one too many a historian of science who likes to talk about "milieu" a little bit too much - the "milieu" of scientists evoked by Canguilhem - but had never come to understand hers, herself. She liked talking about "milieu" a lot, but so "Moyen" herself... We warned you : you do us violence, we will return it a thousand times.

- "the orders of the beggars"... Boy oh boy, this text is too much. ' 5 by 5 '

- that was us.

- And, if you do not understand these lines, for what they are, you are really helpless.

— Harvard, MIT, Stanford, Penn ... 
tion of Rome in the Antiquity.

3. And, finally, though marginally, 'election' by luck : of limited reach, in Greek towns of the Antiquity.

The Christian Church had - in theory -

The Church had - in theory - opened access to knowledge and honorary ecclesiastic pleasures, functions to all.

But, in reality, it did else :

Episcopal, abbatial functions and ecclesiastic dignities were largely, only the pleasures of the rich, and the powerful of the time : the Nobility, as pointed out.

The young nobles and soon-to-be young bourgeois took most of these jobs.

The system of the academic world, did, to few, enable a real social ascension. Few only.

The analysis of reality, and our changing times goes beyond the anecdotal : as sociologists we draw up, create general types.

At the very bottom - or top, we should say perhaps - of this professional, social and institutional evolution, was one goal :

Power.
- Spratacus (1960).

- Rappers. Baskteball players. Movie stars. NFL stars. Soccer players. And, various $\mathrm{TV}$, media personalities too.

- Theory vs practice. Promises vs. acts. Ideas vs. beliefs. - in other words, the material, including mental, and metal structures mentioned at the very beginning.

- The upper-classes' offspring. The 1 to $10 \%$. (e.g. Mark Zuckerberg or Sheryl Sandberg)

-. 1993. Intellectuals in the Middle Ages. Wiley-Blackwell.

-. 2014. Les intellectuels au Moyen Age. Points. 


\section{She looks away, he looks back : translation as reflection of our times.}

\section{Camille Akmut}

Collected thoughts on what it means to translate, in preparation for an upcoming translation. We argue : "In certain songs, we hear our own lyrics.",

"Translations are reflections of our times, and ourselves - and yourselves." and, based on Martha, "She looks away, he looks back." 


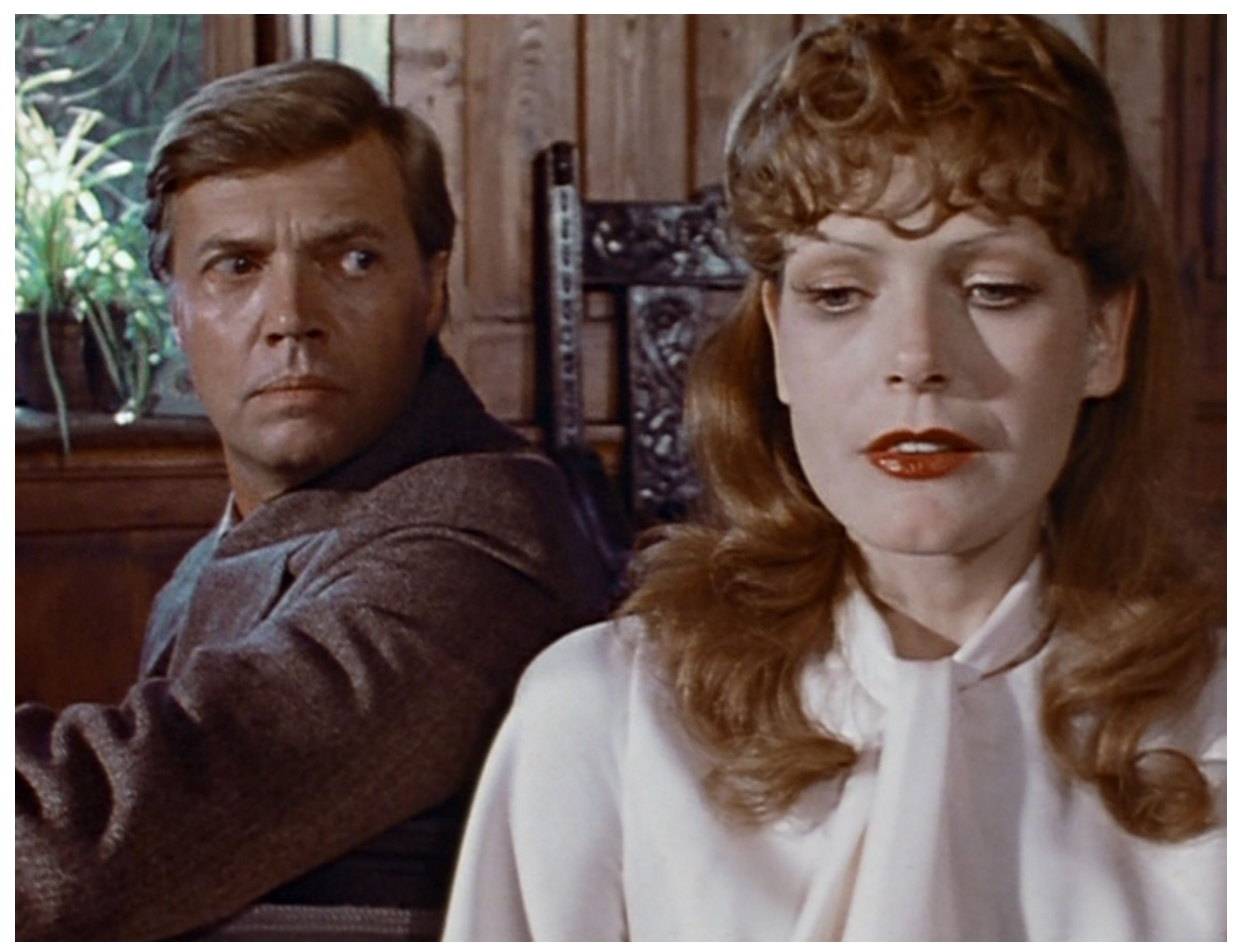

Figure 1: Martha (1974) : She looks away, he looks back. 


\section{The reader played}

In certain songs, we hear our own lyrics.

Like in Unknown Pleasures.

Translation is very much like so.

There is a premise of abuse that is inherent to all translations. "We hurt the ones we love most" - recognized a modern heroine.

The premise alone let's you know so much :

"In certain songs, we hear our own lyrics" we said. We repeat ourselves too. A few examples now :

In The Lonesome Death of Hattie Carroll, a song so great we have to put in italics reserved to works of literature, we cannot help ourselves, we only hear :

\section{"Hattie Carroll was a maid in the kitchen."}

But, apparently, Dylan had meant "of the kitchen". But, "of" sounds a bit too noble for our taste... We associate "of" with Zanzinger instead.

Would you be mad at us if we had translated it so from a foreign language, knowing it was "of(f)"?

Or, would you feel, on the contrary, that you had gained something - more - from "in"?

Maybe you would feel that, in some strange way, we had been more right than even the author knew themselves to be right. Even, if they said so?

The fact that some things escape us : is the very basis for the history of art - as we know. Otherwise, a mere encyclopedia of birth and death dates would be enough to us, even those we lack - and what kind of a world would like a history like that. - only an empty one.

Even if Kubrick, who knew much better than to do this, told anyone such and such film of his, had meant such and such things... It would be neither.

Translation is not for the faint of heart.

Everyone is a master of their own lives?

Unknown pleasures: "abuse", "heroine", "hurt", "mad", "strange", "death", "empty", "faint", "unknown" ...

And, meanwhile, this had all been going on right in front of your eyes, the whole time. We even warned you. (Multiple times!)

And, you will now perhaps agree with us, when we repeat that: "The fact that some things escape us is the basis of art history." Meanwhile, we changed this sentence a little bit. Removed some things, added others.

But, no more tricks we promise! Trust us : But, more importantly, trust yourself.

"Hattie Carroll was made, killed in the kitchen." 
We will perhaps one day find the audacity, and courage, and truth, of writing so. - loveless, and reckless.

\section{Mirror of yourselves}

In another song, we hear as if it were truth :

"I've been waiting for a guy to take me by the hand; and, make me feel the pleasures of another man."

This, we can guarantee, we are not alone in hearing. Whatever, it is much better, so. - and, not "perhaps" only. - or, in addition to being so, perhaps.

But, perhaps Ian Curtis had meant it exactly like that. We'll never know, unless someone translated it.

In another yet, we hear Baldwin's inverted echoes...

In translation acts, the truth is no better than the truth.

We like the mistakes of Panofsky over, in addition to the truth.

We like the Divine Comedy most in the translation of Mark Musa. It is a book of both, and none, like great translations.

We turn writings, like Intellectuals in the Middle Ages, or "The School of Vienna at (the Congress of) Prague", or Inferno, to our times. For, we cannot escape them, nor should we have any wish to do so : they are our times (if we make them, we must).

But, truth, you want?

Truth : We would have to stop loving all of our heroes, and there would be none left, and none left to love them. Or, accept them for what they are : a task so impossible you would have to start accepting yourselves...

"Martha was sooo realistic" - said a dumb Barbie I know. (Myself.)

It was not realistic : It was real.

In Martha, everything is! That is what makes it so shocking, and profoundly disturbing, groundbreaking. Hyper-realism. Everything is so real that we must leave out the italics.

Do you not get it? When the male protagonist screams "Martha" from down the stairs : what you are hearing, and seeing, is - in the most blunt and brutal way possible - Fassbinder screaming in atrocity at himself.

Our translations are reflections of our times, and ourselves - and yourselves. In a translation, we start with an act of abuse : to the ones we love the most. 